\title{
Seasonal Appearences of Short-tailed (Puffinus tenuirostris) and Sooty (Puffinus griseus) Shearwaters on the Tokyo-Kushiro Line, Japan
}

\author{
Yoshiki Watabe*1, Nariko Oka** and Naoki Maruyama*
}

\begin{abstract}
The short-tailed (Puffinus tenuirostris) and Sooty (Puffinus griseus) Shearwaters were counted from the ferry boat during eleven voyages between Tokyo and Kushiro from December 1982 to March 1984. More than 90 percent of both shearwaters were observed during the voyages from April to June, during their spring migration. The appearence of Sooty Shearwaters reached a peak in early May along the Pacific coasts of northern Honshu, one month earlier than Short-tailed Shearwaters. Their early occurrence suggests that these Sooty Shearwaters were adult birds. During the autumn migration season both shearwaters were observed to be limited in the waters off Hokkaido. Only a few birds of both shearwaters were observed in mid summer and winter. The emaciated birds of both species were observed during the voyages in mid June, 1983, but most of them were Short-tailed Shearwaters and they were also observed in late September to early October in that year.
\end{abstract}

\section{Introduction}

The migration route of Short-tailed Shearwaters, proposed by Serventy (1953), has been criticized by Shuntov (1972) and Guzman (1981). In 1983-85, we carried out 11 round trans-pacific surveys to find their actual migration routes in the temperate North Pacific. The above studies covered an extensive pelagic sea area, but include few coastal local information, other than Guzman (1981) who surveyed the local waters off Alaska and British Columbia. Along the Japanese Pacific coast, mortalities of this shearwater have occurred regularly from late May to mid June of every year (Oka et al. 1985), and those of high or middle magnitude have been reported with intervals of about 10 years (Oka \& Maruyama 1986). However, few data on their migration routes were available for the Japanese waters. Therefore, Degawa \& Watabe (1983) made pelagic counts from the ferries of the Tokyo-Ogasawara Line, March to July and the TokyoKushiro Line, July, 1982. As a result, and considering other seabird watcher's data, they suggested that migration routes may pass east of $140^{\circ} \mathrm{E}$ and may differ by age.

The Sooty Shearwaters, a close relative of the Short-tails, breed in New Zealand and southeastern Australia (also southern South America) and are found off Japan during the northward migration, but with much less mortality than the Short-tails (Oka et al. 1985). A comparative analysis of data on these two shearwaters in the Japanese waters may help

Received 28 May 1987

* Department of Environmental Science and Conservation, Faculty of Agriculture, Tokyo Noko University, 3-5-8 Saiwaicho, Fuchu, Tokyo 183.

1 Present address; Environmental Control Centre, 129 Ueda, Hino, Tokyo 191.

** Yamashina Institute for Ornithology, Konoyama, Abiko City, Chiba 270-11, Japan. 
understand the real status of mass mortality of the Short-tails and their ecological segregation from the Sooties.

Here, we report the results of monthly counts of the two shearwaters made on offshore navigation course from Tateyama, central Honshu, to Kushiro, Hokkaido.

\section{Study Area and Methods}

The Short-tailed and Sooty Shearwaters were counted over the waters between Tokyo Bay and Kushiro Harbour by using regular ferry boats $(9,000 \mathrm{t})$, cruising at about 20 knots per hour. Daytime counts were available on two sea sections: from Tateyama to Sendai, about $400 \mathrm{~km}$, and from Cape Erimo to Kushiro, about $170 \mathrm{~km}$, but data in

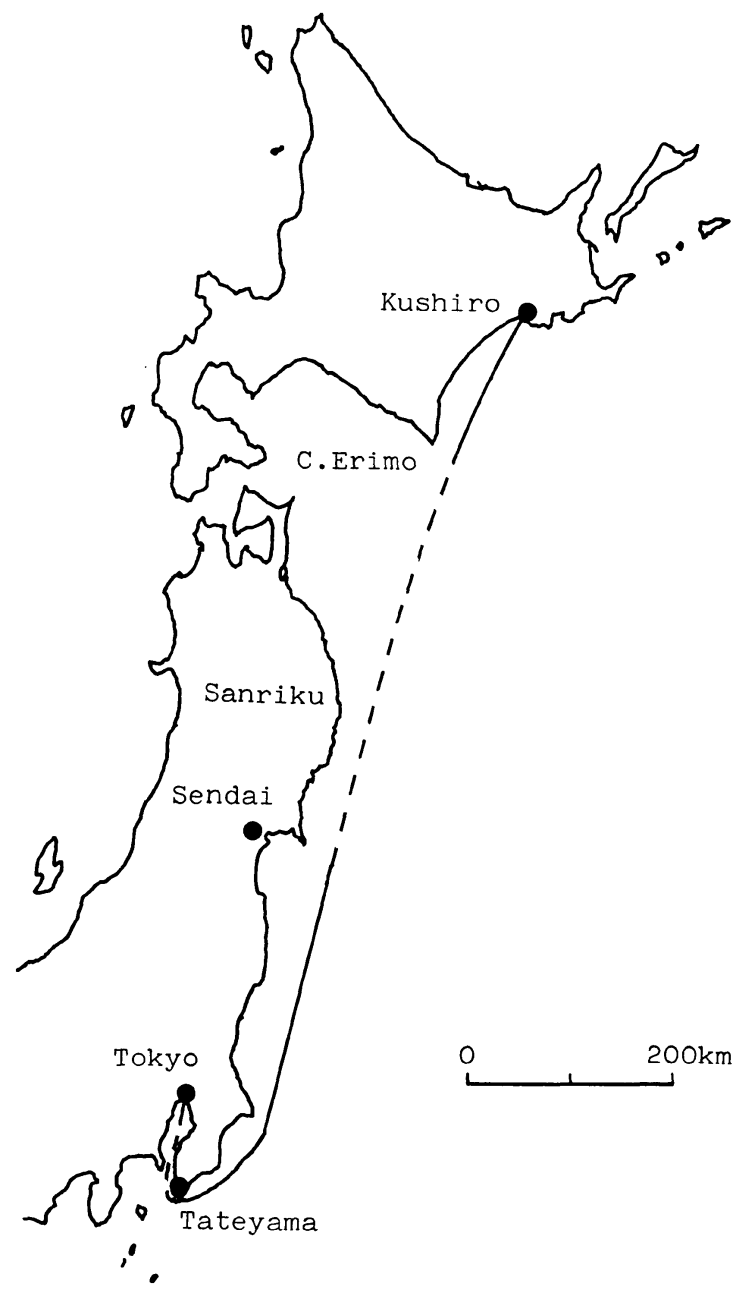

Fig. 1. Census route from Tokyo to Kushiro.

The broken line shows the portion traveled at night. 
Sanriku sea area were lacking owing to night navigation (Fig. 1).

The counts were carried out almost monthly during 11 round voyages from late December in 1982 to early March in 1984. It took 15-24 hours from off Tateyama to Sendai and 5-8 hours from off Cape Erimo to Kushiro. Observations were made with binoculars $(\times 8)$ from the lower deck about 8 meters above the water. All the visible birds from one side of the ship were recorded along with their behavior. The Shorttailed and Sooty Shearwaters were carefully identified according to the following criteria (Ogi 1982): the wing undercoverts are more whitish silver grey in the Sooty than in the Short-tail. The body shape is more stocky in the Sooty. The head looks smaller and more round in Short-tail than the other. The Short-tail flaps more rapidly and turns more quickly than the Sooty.

\section{Results}

The total numbers of the Short-tailed and Sooty Shearwaters counted during the whole voyage were about equal; 3,009 Short-tails and 3,089 Sooties. 2,895 (96.2\%) Short-tails and $2,827(91.5 \%)$ Sooties were observed on their spring migration from April to June (Table 1). In the sea area from off Tateyama to Sendai, the most of the Sooty, 2,683 birds, appeared on May 3-5, which was one month earlier than the Shorttail, 2,453 birds, recorded during June $15-17$ in the same waters. The number of Sooties was more than $4.0 / \mathrm{km}$ which far exceeded the values in other months. On the other hand, in the waters from off Cape Erimo to Kushiro the number of Short-tails was $0.2 / \mathrm{km}$ and $1.5 / \mathrm{km}$ during the voyages of April 8-10 and June 15-17, respectively, while the Sooty was rarely seen.

In autumn migration, most of the 106 Short-tails recorded were observed only in the waters from off Cape Erimo to Kushiro, from the end of September to early November, and most of the 257 Sooties were also observed in the same waters from the end of August to early November. Both shearwaters showed the peak during the same voyage of September $30-O c t o b e r 2 ; 65$ Short-tails $(0.3 / \mathrm{km})$ and 162 Sooties $(0.8 / \mathrm{km})$. Here, too, the Sooty occurred one month earlier than the Short-tail. In mid summer and winter only 8 Short-tails and 5 Sooties were observed.

Behavior of the birds approached by ship was an index of emaciation for migrating Short-tails (Nishigai et al. 1981). The birds observed in spring and autumn belonged to the following 2 groups; one, the floating birds and the other, flying or taking-off when the ship approached (Table 2). In the voyage of June 15-17, 1,468 birds were floating helplessly, and accounted for $54.9 \%$ of the total of Short-tails. On the other hand, only 17 Sooties were observed floating. Most $(90.7 \%)$ of the emaciated Short-tails were observed in the waters of off Tateyama-Sendai, and the remainning $10 \%$ were observed in the waters of off Cape Erimo to Kushiro. In the voyage of September 30-October 2, only 65 Short-tails were counted in the waters of off Cape Erimo to Kushiro, and six $(9.2 \%)$ of them appeared to be emaciated. However, no Sooty was observed emaciated in autumn. 


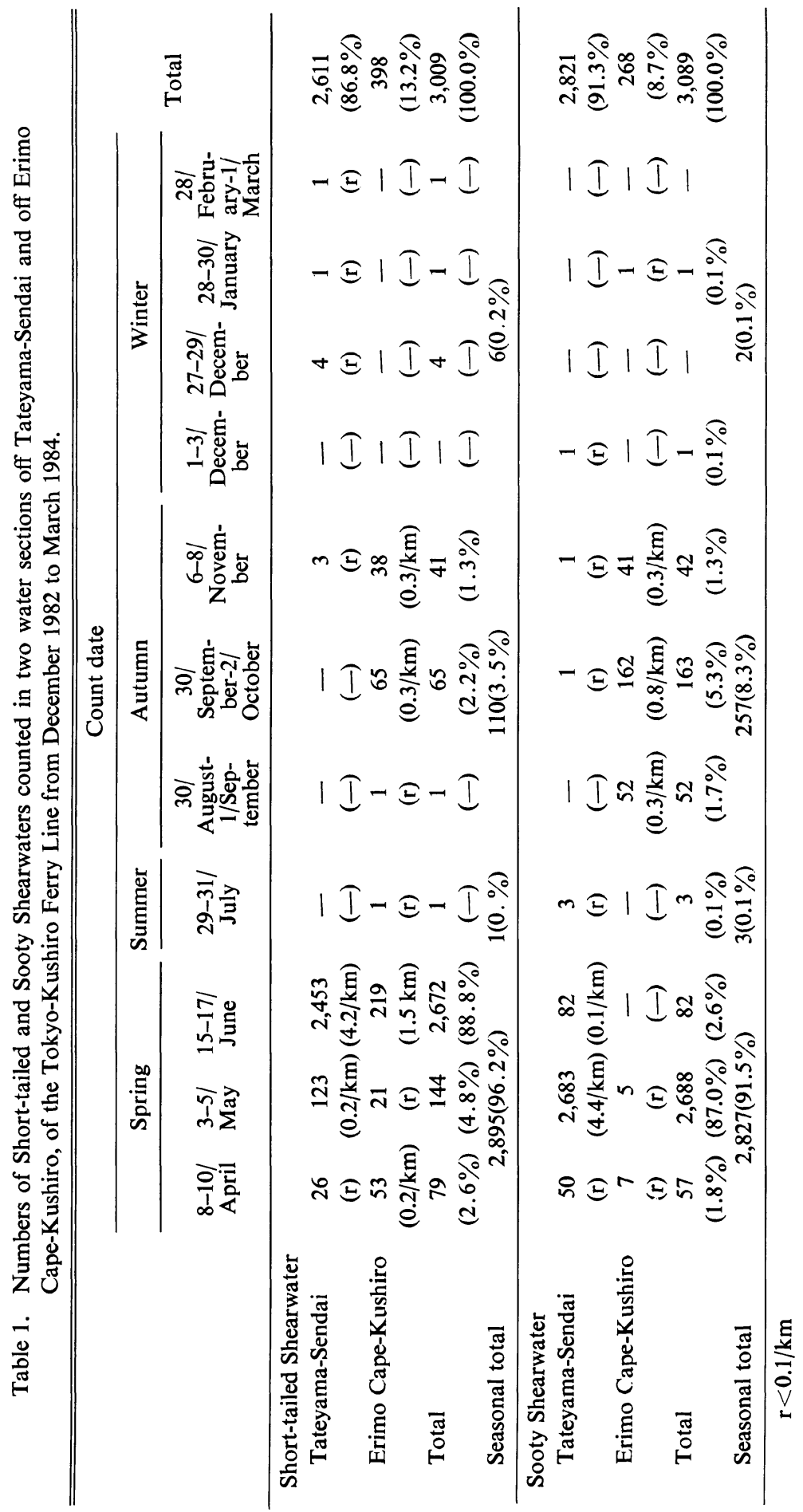




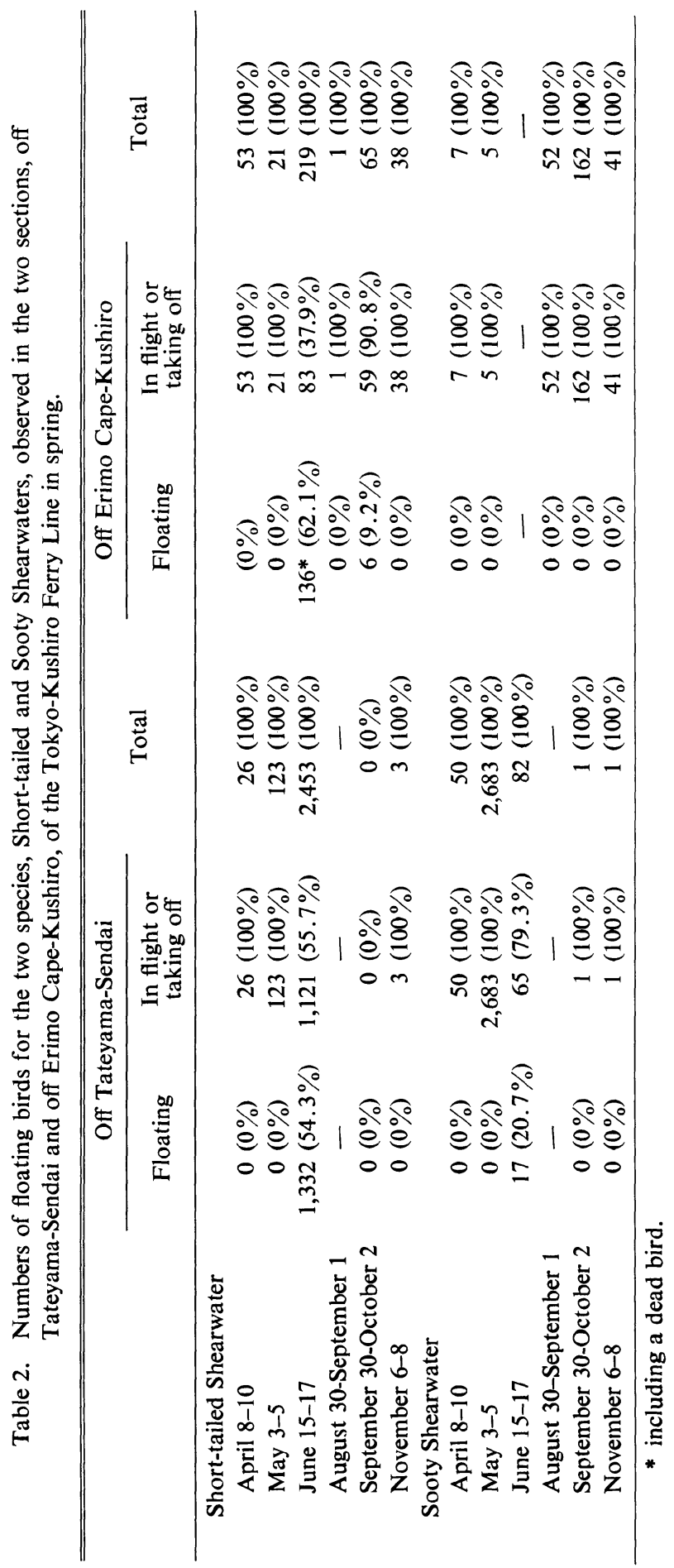




\section{Discussion}

The first group of birds observed along the Japanese coast in the voyages of early April and early May were considered to be subadults and adults, because they are known to depart the breeding area from March to mid April, more than two weeks earlier than young of the year. They need, at least, two to four weeks to reach the Japanese shore. The birds found along the Japanese waters after about May 20 may be young of the year (Oka \& Maruyama (1986) reported that more than $99 \%$ of dead birds found along the Japanese coast in this season were young of the year). Therefore, we consider that age composition of the birds migrating north off the Japanese coast in spring are mostly biased to young of the year. In the breeding areas, the total population of adults and subadults has been estimated at more than 13,000,000 individuals, in contrast to the population of young of the year, 3,250,000 (Naarding 1981). As suggested by Guzman (1981), Degawa \& Watabe (1983) and our recent trans-pacific survey, the northward migration routes would be different by age. Most of the older birds would migrate through central pealgic sea areas, and most of young of the year should take more drifted routes closer to the Japanese coast.

The birds observed in the waters of off Cape Erimo to Kushiro during the end of September and early November were regarded as nonbreeders migrating to the southern hemisphere, considering from their breeding schedule (Serventy 1967). The birds observed in winter may be nonbreeders and may include young of the year which may not necessarily return to the breeding area (Kuroda 1963, Shuntov 1974, Degawa \& Watabe 1983). The summering waters of this species along the Japanese Pacific coast may be north of $44.0^{\circ} \mathrm{N}$ along Hokkaido (Oka 1986), where large numbers of the birds were feeding in early July there (Tanaka \& Kajiwara 1979). No bird was observed in the temperate waters along the Japanese Pacific coast in this season.

The year, 1983, is known by mass mortalities of this species in the temperate Japanese waters (Oka \& Maruyama 1986). Accordingly, greater number of emaciated birds were possibly considered to be there in June of this year than in other years. Moreover in the voyage of September 30-October 2 of the same year, the emaciated birds were again observed. Gibson (1984) reported mass moratilities of this species off the Kodiak, Dutch Harbor of the Aleutian Islands and Seward Peninsula in Bering Sea from late August to late September in 1983 . One of the possible causes may be abnormally high sea temperature reducing the food resource, as was reported by Gibson (1984).

Summering waters of the Sooty Shearwater in the northern North Pacific are situated south of those of the Short-tailed Shearwater (Ogi et al. 1980, Ogi 1984). Chu (1984) reported that many Sooties molting the wings were found in the Monterey Bay near San Francisco between May and August. Also in the waters off Sanriku, northern Honshu, Japan, some Sooty Shearwaters were observed molting the wings in late May (Kuroda 1954). Further, Kuroda (1954) suggested these molting birds fatty. This indicates that the waters off Sanriku would be a potential summer range of this species. Nevertheless, only a few birds were observed in the sea areas surveyed in mid summer. Therefore, the sea areas off nothern Honshu may be the southernmost summering 
waters for the Sooty, and the main populations probably migrate to the waters further north than Kushiro $\left(43^{\circ} \mathrm{N}\right)$.

\section{Acknowledgements}

We are grateful to the officers of the ferry boats, the Marimo-maru and the Saromamaru for giving cruising information to us. We would like to thank Dr. N. Kuroda, Vice President of the Yamashina Institute for Ornithology, for correcting English in this manuscript, and we are greatly indebted to the Toyota Foundation for financial sponsorship for this study.

\section{References}

Chu, E. W. 1984. Sooty shearwaters off California: diet and energy gain. In Marine Birds: their feeding ecology and commercial fisheries relationships (Ed. by Nettleship et al.): 64-71.

Degawa, M. \& Watabe, Y. 1983. Distribution of the Short-tailed Shearwater Puffinus tenuirostris in Japanese waters. Bull. Applied Ornith. 3: 19-27.

Gibson, D. D. 1984. Alaska region. American Birds 38: 234-236.

Guzman, J. R. 1981. The wintering of Sooty and Short-tailed Shearwaters (genus Puffinus) in the north Pacific. Ph. D. thesis, University of Calgary, Calgary, Alberta, Canada.

Kuroda, N. 1954. On the wildlife off Iwate Prefecture. Nihonryouyu No. 42: 3. (In Japanese)

Kuroda, N. 1963. A winter sea-bird census between Tokyo and Kushiro, Hokkaido. Misc. Rep. Yamashina Inst. Ornith. Zool. 3 : 227-238.

Naarding, J. A. 1980. Study of the short-tailed shearwater Puffinus tenuirostris in Tasmania. $78 \mathrm{pp.}$ National Parks and Wildlife Service of Tasmania.

Nishigai, M., Saeki, Y., Ishitani, R., Sugimori, F., Ishibashi, Y., Oka, N. \& Nakama, A. 1981. Pathological investigations on cause of death in slender-billed shearwater collected in Johga-shima area. J. Yamashina Inst. Ornith. 13: 82-89. (In Japanese with English summary)

Ogi, H. 1982. Identification guide to seabirds in northern North Pacific. The Fisheries Agency of Japan. $102 \mathrm{pp}$.

Ogi, H. 1984. Feeding ecology of the Sooty Shearwater in the western subarctic North Pacific Ocean. In Marine Birds: their feeding ecology and commercial fisheries relationships (Ed. by Nettleship et al.): 78-85.

Ogi, H., Kubodera, T. \& Nakamura, K. 1980. The pelagic feeding ecology of the short-tailed shearwaters Puffinus tenuirostris, in the subarctic Pacific region. J. Yamashina Inst. Ornith. 12: 157-182.

Oka, N. 1986. Observation on the emaciated and dead Short-tailed Shearwaters, Puffinus tenuirostris, in the north-western sea area of the North Pacific in 1983. J. Yamashina Inst. Ornith. 18: 63-67. (In Japanese with English summary)

Oka, N. \& Maruyama, N. 1986. Mass mortality of Short-tailed Shearwaters along the Japanese Coast. Tori 35: 97-104.

Oka, N., Sugimori, F. \& Ishibashi, Y. 1985. Mortality counts of Short-tailed Shearwaters Puffinus tenuirostris at Shiinauchihama of Kujukuri-beach, 1976-1982. J. Yamashina Inst. Ornith. 17: 113-117.

Ozawa, K. 1964. Records and observations of an unusual wreck of Slender-billed Shearwater on the Pacific coast of Japan, end of May 1964. Misc. Rep. Yamashina Inst. Ornith. 4: 114-117. (In Japanese with English summary)

Serventy, D. L. 1953. Movements of pelagic sea-birds in the Indo-pacific region. In Proc. 7th Pacific Sci. Congr.: 394-407.

Serventy, D.L.1967. Aspects of the population ecology of the short-tailed shearwater Puffinus tenuirostris. In Proc. XIV I.O.C. (Ed. by Snow), Oxford: 165-190. 
Shuntov, V. P. 1972. Sea birds and biological structure of the ocean. (Translated from Russian). NTIS, U. S. Dept. of Comm. 1974: 74-92 pp.

Sugimori, F., Oka, N. \& Iwase, Y. 1976. An questionnaire survey of shearwater mortality, especially of Puffinus tenuirostris. Rep. Yamashina Inst. Ornith. 8: 113-131. (In Japanese with English summary)

Tanaka, H. \& Kajiwara, T. 1979. The distribution of Fulmarus glacialis and Puffinus tenuirostris, in the North Pacific Ocean and the Okhotsk Sea during the summer. J. Yamashina Inst. Ornith. 11: 7986. (In Japanese with English summary)

\section{東京-釧路航路におけるハシボソミズナギドリと ハイイロミズナギドリの出現の季節的変化}

1982 年 12 月から 1984 年 3 月にかけて東京-釧路間フェリー航路を, 計 11 回往復し, ハシボソミズナ ギドリとハイイロミズナギドリの出現状況を調査した。両種とも全観察数の $90 \%$ 以上が 4 月から 6 月の春 期航海に集中したものの, 出現ピークは, ハイイロでは 5 月初旬, ハシボソでは 6 月中旬の調査時に認め られた。この結果から, 八イイロでは少なからぬ成鳥群が, 日本沿海部を通過することが示唆された。一 方, 盛夏, 冬期間では, 両種とも極めてわずかが観察されたにすぎなかった。6月中旬の調查時にハシボ ソでは出現鳥の 50\% を越える計 1,468 羽と, 若干のハイイロに衰弱鳥がみられ, さらに, 秋の渡り時の 9 月下旬から 10 月初旬の調査時にも出現鳥の $10 \%$ 近く (9 羽) のハシボソに衰弱鳥がみられた。

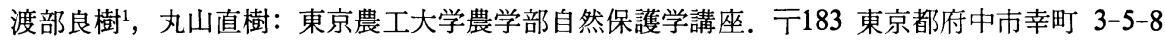

岡 奈理子：(財) 山階鳥類研究所. 干270-11 千葉県我孫子市高野山字堤根 115

1 現在: (株) 環境管理センター 